\title{
The Magic of Undiscouraged Effort: The Death Penalty in Early Iowa, 1838-1878
}

\section{RICHARD ACTON}

IN 1872 Iowa became the fourth state in the United States to abolish the death penalty. Six years later it became the first state to restore capital punishment. Surprisingly, no one has ever given a complete account of those developments. ${ }^{1}$ In this article, I attempt to fill the gap with equal emphasis on the abolition and restoration of the death penalty.

The full story of the abolition of the death penalty in 1872 does not reveal the amassing of large and irresistible social forces to sweep away a barbaric punishment. After all, the Iowa legislature restored the death penalty only six years later. The story is more about the susceptibility of a vital number of legislators to current events and public pressures than about a conflict of ideologies.

In the sixteen votes on capital punishment in the Iowa House of Representatives or Senate between 1851 and 1878, those opposed to the death penalty always obtained at least onethird of the votes, while the share of those seeking to retain it was, at its lowest, just under a third. The impressionable remainder of legislators thus held the balance of power. Those legisla-

I wish to thank my wife, Patricia, and Karen Laughlin, Susan Rogers, and Melanie Datz of the library of the State Historical Society of Iowa, Iowa City, for their invaluable assistance in preparing this article.

1. Hugo Adam Bedau, The Death Penalty in America, 3d ed. (New York, 1982), $22-23$, called for accounts of the reintroduction of the death penalty in several states, including Iowa, no more than a few years after it had been abolished.

THE ANNALS OF IOWA 50 (Winter 1991). CThe State Historical Society of Iowa, 1991. 
tors must be the focal point for explaining why Iowa abolished and then restored capital punishment in a mere six years.

In this article, I first describe the beginnings and apparent entrenchment of capital punishment in Iowa between 1838 and 1870. Then I set out the events and influences that persuaded the volatile controlling minority in 1872 to vote suddenly and overwhelmingly to abolish the death penalty, and only six years later to change sides and vote overwhelmingly to restore it.

AT ITS BIRTH on July 4, 1838, the Territory of Iowa inherited a Michigan territorial law that punished murder with public hanging. ${ }^{2}$ Prominent voices of reform were raised from the outset. In November Governor Robert Lucas, in his first message to the Iowa Territorial Assembly, declared that he favored the abolition of capital punishment and advocated life imprisonment as the maximum penalty. He reluctantly conceded the need for the death penalty until the erection of a penitentiary; however, he wanted to exclude the public from executions. The sole newspaper in Burlington, the territorial capital, supported Lucas's views. The Assembly forthwith passed a criminal code that specified hanging as the punishment for murder. It was left to the court whether executions should be private or public. ${ }^{3}$

Although lynchings occurred periodically in Iowa from 1834 onwards, there were no legal executions in the early territorial period. ${ }^{4}$ Nonetheless, the death penalty remained a public issue. In 1842 the Lyceum in the new territorial capital of Iowa City announced its first discussion would be, "Ought capital punishment to exist by law?"5

2. "An Act for the Punishment of Crimes," $\S \S 1,58,65$, Laws of the Territory of Michigan (Detroit, 1833), 444, 461, 462.

3. Benjamin F. Shambaugh, ed., The Messages and Proclamations of the Governors of Iowa, 7 vols. (Iowa City, 1903-1905), 1:82-83; Iowa Territorial Gazette and Burlington Advertiser, 24 November 1838; "An Act Defining Crimes and Punishments," §§ 1, 2, 101, Laws of Iowa 1838-39, 150, 151, 180. The size of the vote was not recorded.

4. Eliphalet Price, "The Execution of Patrick O'Connor," Palimpsest 1 (1920), 86-97; Paul Walton Black, "Some Sociological Aspects of Lynchings in Iowa," (M.A. thesis, University of Iowa, 1911), table 5.

5. Iowa Capital Reporter (Iowa City), 15 January 1842. 
Similar public debates took place in the 1840s in almost all of the northern states. The most vocal public defenders of the gallows were Calvinist clergy, especially Presbyterians and Congregationalists. Their primary arguments were that God had ordained capital punishment in Genesis 9:6, "Whoso sheddeth man's blood, by man shall his blood be shed," and that the death penalty deterred murders. The reformers countered that the biblical commandment, "Thou shalt not kill," applied to the state, and that Christianity taught mercy. Citing European examples, they urged that life imprisonment was a more effective deterrent.

Thousands of reformers agitated to abolish the hangman for humanitarian reasons. The movement drew largely on free thinkers, Unitarians, Universalists, and Quakers. Newspaper magnates such as Horace Greeley of the New York Tribune and professional reformers such as William Lloyd Garrison and Wendell Phillips threw themselves into the fray. U.S. VicePresident George M. Dallas lent his name to the cause. Abolition societies sprang up in the early 1840s in Pennsylvania, New York, Massachusetts, and elsewhere. In 1845 a national coordinating organization-the American Society for the Abolition of Capital Punishment-was launched. Newspaper articles, books, pamphlets, lectures, debates, and petitions to legislatures poured from the state societies. ${ }^{6}$ Michigan raised the hopes of reformers in 1846 when it became the first state to abolish the death penalty for murder (although retaining it for treason) ${ }^{7}$

In June 1845 Iowa's first legal executions took place. William and Stephen Hodges, young Mormons from Nauvoo, Illinois, were convicted of murder in Burlington and sentenced

6. Philip English Mackey,Voices Against Death: American Opposition to Capital Punishment, 1787-1975 (New York, 1976), xxii-xxvi; Louis P. Masur, Rites of Execution: Capital Punishment and the Transformation of American Culture, 1776-1865 (New York, 1989), 117-56; David Brion Davis, "The Movement to Abolish Capital Punishment in America, 1787-1861," American Historical Review 63 (1967), 23-46; Louis Filler, "Movements to Abolish the Death Penalty in the United States," Annals of the American Academy of Political and Social Science 28 (1952), 124-36.

7. Albert Post, "Michigan Abolishes Capital Punishment," Michigan History Magazine 29 (1945), 44-50; Edward W. Bennett, "The Reasons for Michigan's Abolition of Capital Punishment," Michigan History (1978), 42-55. 
to public hanging. The town was packed from dawn, and steamers brought crowds from Muscatine, Fort Madison, and Illinois. Ten thousand people watched the gruesome executions as William Hodges struggled for ten minutes before he died. ${ }^{8}$

A few months after the hangings, Iowans established their own abolition society. In January 1846 Charles Mason, chief justice of the territorial supreme court, presided over a large meeting in Iowa City to launch the Iowa Anti-Capital Punishment and Prison Discipline Society. The meeting denounced the death penalty as barbaric, vengeful, brutalizing of spectators, founded on hoary prejudice, and opposed to Christianity. ${ }^{9}$

The next year Chief Justice Mason gave a powerful address to the Iowa society. He declared that the death penalty did not deter crimes, that murder had not increased during periods of abolition in foreign countries, that innocent people had been executed, and that Christ preached forgiveness. The Iowa society made its mark nationally when the New York society published Mason's address and sent it to members of seven state legislatures. In 1849 the Prisoner's Friend, the reform movement's own newspaper, announced that in Iowa "the law is near being abolished."10

In Iowa's first legislative attempt at reform in 1847, the Senate had in fact narrowly passed a bill giving the jury the choice whether to punish murder with death or life imprisonment. But in the House the two sides exchanged Old and New Testament quotations before voting 21 to 12 to postpone the bill indefinitely. ${ }^{11}$ In 1851 leading members of the Iowa society did even better as they actually did nearly abolish the death penalty.

8. Burlington Hawkeye, 16 July 1845. Information about executions in early Iowa can be found in David D. Reineke, "Capital Punishment in Early Iowa, 1834-1898" (manuscript, State Historical Society of Iowa, Iowa City).

9. Iowa Capital Reporter, 28 January 1846. Former territorial governor Robert Lucas was elected president, and Chief Justice Mason vice-president.

10. Address of the Hon. Charles Mason Before the Iowa Anti-Capital Punishment and Prison Discipline Society on the 11th of January, 1847 (New York, 1848), 13, 24; Philip English Mackey, Hanging in the Balance: The Anti-Capital Punishment Movement in New York State, 1776-1861 (New York, 1982), 257-58; Prisoner's Friend, March 1849, 316.

11. Burlington Hawkeye, 11 February 1847; 1847 Iowa Senate Journal 152, 159; 1847 Iowa House Journal 239. 
After Iowa achieved statehood in 1846, Chief Justice Mason became chairman of a three-man commission to produce a revised Code of Laws. Mason sought abolition, but his fellow commissioners disagreed, and the death penalty was retained in the body of the draft code. However, Mason managed to insert an appendix into the code abolishing capital punishment. When the House considered the draft code in 1851 , it wrongly assumed the appendix was part of the code and the work of all the commissioners, one of whom, Stephen Hempstead, had since been elected governor. The House narrowly passed the abolition clause in the appendix on the second reading, 19 to 17 . The powerful antigallows Senator George G. Wright led the Senate to pass the clause on the second reading, 10 to $8 .{ }^{12}$

Headlines of "Capital Punishment Abolished in Iowa" greeted this news. Only the formality of the third reading of the entire code remained. But the following Sunday, an Iowa City Presbyterian minister stopped abolition in its tracks. Many members of the General Assembly were present as "the Rev. Mr. Hazzard came out ... in favor of Capital punishment and in opposition to the action of the General assembly upon this subject." 13

After Rev. Silas H. Hazzard's sermon, House and Senate committees inquired into the origins of the appendix. As a result, legislators realized that it was solely Mason's work and that his colleagues (including the new governor) had considered it "of doubtful propriety." On the final day of the session the House passed a joint resolution that the appendix was not part of the code. When the Senate refused to concur, it looked like a deadlock. But the House persisted, striking the appendix out of the code by a large majority and then passing the entire code. Senator Wright, despite his desire to abolish the death penalty,

12. A Portion of the Report of the Commissioners Appointed to Draft, Revise, and Arrange a Code of Laws (Iowa City, 1850), 320, 326, 327; Clifford Powell, "History of the Codes of Iowa Law," part 2, "The Code of 1851," Iowa Journal of History and Politics 10 (1912), 8-14; Proceedings of the Pioneer Lawmakers Association of Iowa Reunion of 1896 (Des Moines, 1897), 58; 1850-51 Iowa House Journal 278; 1850-51 Iowa Senate Journal 255.

13. Iowa Star (Fort Des Moines), 6 February 1851; Valley Whig and Keokuk Register, 6 February 1851; Dubuque Miners' Express, 12 February 1851. 
advised the Senate to accept the House version lest the entire code be lost. The Senate acquiesced and easily passed the whole code without the appendix. In the final hour of the session, the Senate made a parting gesture of principle by passing a separate abolition bill. The reformers did make one gain. The legislature accepted the commissioners' recommendation that only premeditated murder in the first degree (and treason) would henceforth be punished with death. Second degree murder was to be penalized by a minimum of ten years' imprisonment. ${ }^{14}$

But for Rev. Hazzard's sermon, Iowa could have been the first jurisdiction in the English-speaking world to pass a law totally abolishing the death penalty. The 1851 House demonstrated-not for the last time-how shallow some legislators' views were on capital punishment. Seven of the nineteen members who had voted for abolition before Rev. Hazzard's sermon changed sides within eleven days. Nonetheless, the vote showed a substantial overall reform minority. The last recorded combined vote of the two houses was 29 for retention and 23 for abolition. ${ }^{15}$

After 1851 the Iowa Anti-Capital Punishment Society withered away. Mason moved to Washington, D.C., and William Penn Clarke, the society's secretary, turned his energies to the antislavery cause. In this Clarke emulated the activists of the eastern societies, who in the late 1840 s and early 1850 s threw themselves into the antislavery movement. ${ }^{16}$

Just as those societies faded, Rhode Island and Wisconsin abolished the death penalty. The historian of capital punishment in Rhode Island concluded, "In 1852 Rhode Island possessed a unique set of characteristics which permitted her-

14. 1850-51 Iowa House Journal 296, 310-12, 347, 353-54, 370, 378-80; 1850-51 Iowa Senate Journal 253-56, 296-98, 314, 321-23; Burlington Hawkeye, 13 February 1851; Report of the Commissioners, 390, 327-28; Valley Whig and Keokuk Register, 13 February 1851; The Code of Iowa, 1851, §§ 256970, pp. 348-49.

15. William J. Bowers, Legal Homicide: Death as Punishment in America, 18641982 (Boston, 1984), 9; 1850-51 Iowa House Journal 379-80. The seven who changed to retentionist were Representatives Goodenow, Harbour, Major, McCulloch, Preston, Summers, and Temple. Representative Negus switched from retention to abolition.

16. Eric McKinley Erikson, "William Penn Clarke," Iowa Journal of History and Politics 25 (1927), 52, 38-44; Mackey, Voices Against Death, xxvii-xxix. 
alone among eastern states-to abolish capital punishment. She had a talented and tireless reform leader in Thomas R. Hazard. She had recently executed a man whom some thought innocent, others too hastily killed. Her size, traditions, and religious composition made her especially vulnerable to reformers." ${ }^{17}$ In Wisconsin a rare and gruesome hanging had occurred in 1851. The following year a jury refused to convict a man generally regarded as guilty, demonstrating the reluctance of juries to convict where the death penalty was mandatory. Reformers and those concerned with lack of convictions banded together to convince the Wisconsin legislature in 1853 to abolish the death penalty. A farmer and state senator of Quaker and Unitarian background named Marvin H. Bovee received credit for the Wisconsin triumph. ${ }^{18}$ In 1872 he was to lead Iowa's abolition campaign.

In Iowa as in Rhode Island and Wisconsin, executions continued to stir those opposed to the gallows. A hanging in 1858 and three more in 1860 took place before vast crowds. Lynchings reached a peak of nineteen in $1857 .{ }^{19}$ Although the Iowa AntiCapital Punishment Society had dispersed, a sizeable minority of legislators kept its goal on the state agenda. In 1856 the House indefinitely postponed an abolition bill by 41 votes to 22 . In 1860 Quakers presented reform petitions to both houses. A motion in the House to refer the Quaker petition to a committee was defeated, 46 to 34. A similar vote in the Senate lost, 21 to $16 .{ }^{20}$

17. Philip English Mackey, "'The Result May Be Glorious'-Anti-Gallows Movement in Rhode Island, 1838-1852," Rhode Island History 33 (1974), 30.

18. Mackey, Voices Against Death, xxvii-xxix; Elwood R. McIntyre, "A Farmer Halts the Hangman: The Story of Marvin Bovee," Wisconsin Magazine of History 42 (1958-59), 3-6.

19. Pioneer History of Davis County, Iowa (Bloomfield, [1927]), 378; History of Delaware County, Iowa (Chicago, 1878), 399-400. Large crowds continued even after hanging had been confined to the jailhouse yard by the 1860 legislature. Revision of 1860, § 4891, p. 825; Clifford Powell, "History of the Codes of Iowa Law," part 3, "The Revision of 1860," Iowa Journal of History and Politics 10 (1912), 330-31, 341, 343, 354; History of Dubuque County, Iowa (Chicago, 1880), 452-53; Letter to the Sheriff of Clinton County, quoted in William Salter, The Life of James W. Grimes (New York, 1876), 93-94; Black, "Sociological Aspects of Lynchings," table 5.

20. 1856-57 Iowa House Journal 131-32; 1860 Iowa House Journal 212-13; 1860 Iowa Senate Journal 243. 
Antigallows efforts stopped in Iowa and other states during the Civil War. Marvin Bovee, who was largely responsible for keeping the movement alive at all in the United States, wrote, "It is useless to talk of saving life when we're killing by thousands." ${ }^{21}$ But reform efforts started again in 1868, when a Senate bill to abolish the death penalty was laid on the table by 25 votes to $20 .{ }^{22}$ The closeness of the vote may have prompted Bovee to write in his major book, Christ and the Gallows (1869), "Iowa ... will, ere long, abandon the law of 'blood for blood'."23

In 1870 both houses debated abolition bills. In the House, Representative Samuel Murdock, a Presbyterian, argued that because Wisconsin had abolished the death penalty, murder was rampant and lynching widespread. He emphasized the deterrent effect of capital punishment. Other retentionists pointed out that life sentences were inadequate because after a time governors would invariably pardon murderers. They quoted the biblical injunction, "He that killeth with the sword shall be killed with the sword," and claimed that no one who anybody thought innocent had been hanged in Iowa. The House reformers maintained that the certainty of punishment rather than its severity deterred crime. Statistics for 1868 showed the same number of convictions for first degree murder in Iowa as in Michigan, where the death penalty had been abolished. Capital punishment failed to deter in New York, where murder was commonplace. Conversely, many lynchings took place in Iowa, despite the presence of the death penalty. ${ }^{24}$

In the Senate debate, Quaker-born Senator Jacob G. Vale quoted Jesus Christ, who said, in Vale's words, "I came to save life, not to destroy it." Vale also claimed that public opinion opposed the gallows. He concluded that life imprisonment was preferable, as a man proved innocent after sentencing could be

21. Mackey, Voices Against Death, xxix; Bovee to Wendell Phillips, quoted in Masur, Rites of Execution, 160.

22. 1868 Iowa Senate Journal 518-19.

23. Marvin Bovee, Christ and the Gallows; Or, The Reasons for the Abolition of Capital Punishment (New York, 1869), 283.

24. Des Moines Bulletin Legislative Supplement (1870), nos. 49 and 50, 11 March 1870. 


\section{FIGURE 1}

Votes in Opposition to Capital Punishment IN tHe Iowa General AsSembly, 1851-1878

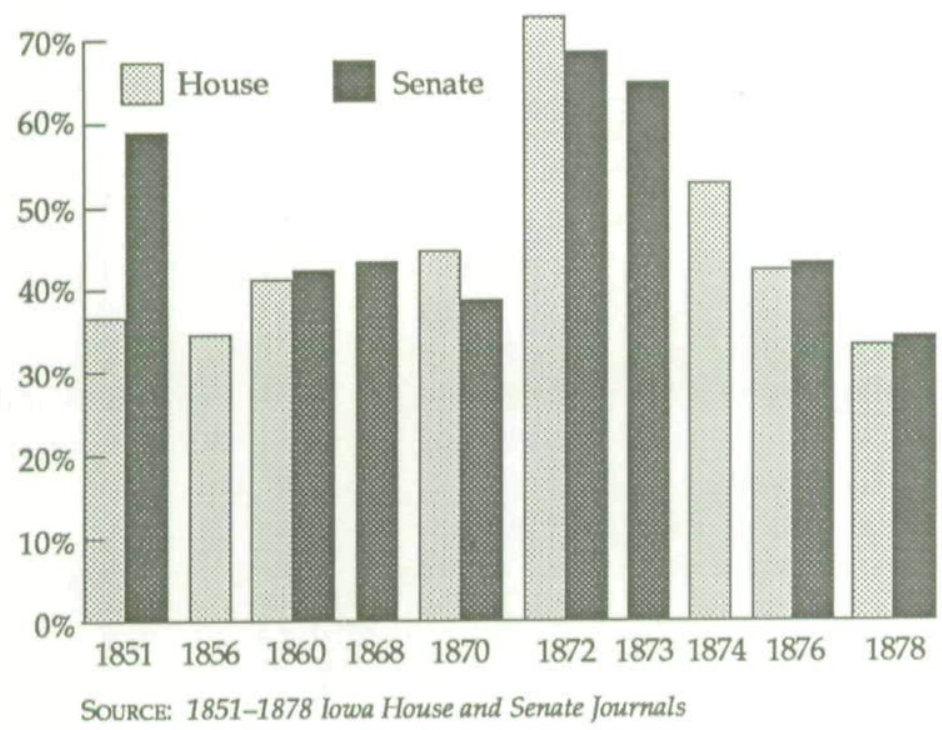

released. On the retentionist side, Presbyterian Senator John McKean believed that lynch mobs were inevitable if the death penalty were abolished. If it was moral to kill "rebels by thousands" in the Civil War, he added, it was moral to inflict the death penalty for murder. The House voted 46 to 38 and the Senate 27 to 17 to retain capital punishment. ${ }^{25}$

Thus in 1870 the legislature yet again rejected abolition. Although reform ideals had taken a firm hold amongst a significant minority of Iowa legislators-in the six votes in the legislature since 1851 the antigallows share was consistently between $35 \%$ and $45 \%$-there had been no sign of a breakthrough by the reformers (see fig. 1). The death penalty seemed firmly entrenched. No one could have foreseen that within two years a dramatic campaign would persuade enough legislators

25. Ibid., no. 43, 28 March 1870; 1870 Iowa House Journal 338-39; 1870 Iowa Senate Journal 382 . The religions and occupations of legislators come from biographies, obituaries, the Iowa State Census of 1895, or The United States Biographical Dictionary, Iowa Volume (Chicago, 1878). 
to change sides for reformers to achieve massive majorities in both houses and thus abolish capital punishment.

A MURDER in June 1870 started the train of events that led to abolition. William Patterson was found shot dead near Ames. The following day a former railway worker named George Stanley was arrested for the murder. There was overwhelming circumstantial evidence against Stanley. He was tried in April 1871 , convicted of murder in the first degree, and sentenced to hang. The Iowa Supreme Court upheld the conviction on February 24, 1872. After reviewing the case, Governor Cyrus C. Carpenter set April 12 as the date for Stanley's execution. Although it would have been the first legal hanging in Iowa since 1865, the Nevada Representative commented, "If the execution of a murder[er] falls to the lot of Story County let the duty be performed unflinchingly." 26

Some people, however, did flinch. Father P. M. Delaney had earlier converted Stanley to Catholicism during his incarceration. Now he and Father John Concannon, his successor as the Boone parish priest, begged Governor Carpenter to reprieve Stanley. A petition for leniency signed by 750 Quakers arrived from Springdale. David Morgan, a Quaker from New Sharon, brought the governor another petition "numerously signed." Governor Carpenter wrote to Father Delaney that he could not justify a reprieve. However, he proclaimed himself an abolitionist who believed in the certainty rather than the severity of punishment-life imprisonment was an adequate deterrent. The governor wrote to David Morgan after their meeting, "The legislature is now in session, and if as you seem to think, the public sentiment is opposed to the death penalty, this General Assembly, which is supposed to represent the average public will, has had every opportunity to wipe out the death penalty." The Register published the governor's letters to Morgan and Delaney, treating them as calls by the governor to abolish the death penalty. Claiming that most senators favored reform, the Register called for the end of "this last relic of a long gone bar-

26. W. O. Payne, The History of Story County, Iowa, 2 vols. (Chicago, 1911) 1:328-31; State v. Stanley, 32 Iowa 526-37 (1871); Nevada Representative, 14 March 1872. 
barism" and the saving of Stanley and Iowa from hanging"the first within its borders for twelve years." (Apparently the writer did not know about the hanging of Benjamin McComb in Ottumwa in 1865). ${ }^{27}$

At the time the governor had set Stanley's execution date, the House of Representatives had resolved to grant to Marvin Bovee of Wisconsin the use of its Assembly Hall on April 4, 1872 , for a lecture on capital punishment. The Register introduced Bovee to Iowa. "Mr. Marvin H. Bovee distinguished in this country and in Europe, as an earnest and successful laborer in the field of penal reform, intends visiting Iowa. . . . Mr. Bovee has been a life-long believer that the inutility and moral mischief of judicial killing demand an abolition of the barbarism. The gentleman is the author of the most telling work ever published in the interest of this special reform." Subsequently the Register wrote that Bovee "has been very successful in all his attempts in the good cause." This last was an exaggeration. Bovee had indeed succeeded in leading the abolition campaign in Wisconsin in 1853, and thereafter had repelled attempts at restoration in that state. He had taken his one-man crusade into Illinois, New York, Massachusetts, Minnesota, and Pennsylvania. In Illinois and Minnesota he had achieved jury option laws. In New York at his instigation a law was passed granting a delay of one year after conviction before execution in case fresh evidence came to light. He had addressed many legislatures and hundreds of public meetings. He had vast experience in lobbying, drafting bills, and wooing editors to his cause. He was the campaigner par excellence. Despite all these remarkable achievements, however, Bovee had nowhere repeated his abolition triumph in Wisconsin. ${ }^{28}$

Bovee arrived in the state capital on April 4 and hurled himself into a whirlwind campaign to abolish the death penalty and save Stanley. He went straight to the governor, who

27. Iowa State Register, 3, 4 April 1872; Boone County Democrat, 5 April 1872; Cyrus Clay Carpenter Diary, 21, 25, 28 March, 2 April 1872, and Cyrus Clay Carpenter Letter Book A, 332, Carpenter Papers, State Historical Society of Iowa, Iowa City. For McComb's hanging, see History of Wapello County, Iowa (Chicago, 1878), 451-52.

28. 1872 Iowa House Journal 450; Iowa State Register, 19, 29 March 1872; McIntyre, "A Farmer Halts the Hangman," 6-9. 
described him as "an earnest sincere man." Bovee gave his major speech that evening in the hall of the House of Representatives "largely attended by members of the Legislature, State officers and citizens of Des Moines. The speaker was introduced by Gov[ernor] Carpenter who presided."29

In his speech Bovee argued that state cruelty led to individual cruelty. No one had a right to kill; still less could one delegate such a right to the state. Human life was sacred. Capital punishment was irremedial-too many people later proved innocent had been executed. "If an individual kill his fellow man, shall the State of Iowa commit a greater outrage by deliberately killing him?" Bovee claimed that capital crimes decreased when the death penalty was abolished, because juries were more likely to convict when their decisions could not lead to hanging. He read letters from prison wardens, governors, judges, and attorney generals in Michigan, Rhode Island, and Wisconsin. They all testified to the "beneficial effects" of the abolition of capital punishment in their states. Bovee stated that mercy and reformation were the trend of the age, and he decried those clergy who stood in the way of abolition. In refuting the Old Testament arguments in favor of capital punishment, he said, "The entire record of Christ's life was in opposition to this doctrine of retaliation." He closed with "an eloquent appeal to the General Assembly to repeal the brutal statute in Iowa." 30

Bovee's speech had a marked effect. House Democratic leader John P. Irish wrote his reaction to Bovee in his Iowa City Press. "I expected ... to see a face sicklied with the sallowness and drawn down to the longitude of the professional philanthropist; but instead he is one of the most manly of men, and delivers his views with a simplicity and directness that have no trace of cant." Both Des Moines newspapers carried lengthy reports of Bovee's speech. The State Leader commented, "For over two hours the speaker enchained his audience with his eloquent exposition of his subject." The Register published a powerful editorial echoing Bovee's ideas that mercy, justice, and humanity required abolition, that the purpose of law was

29. Cyrus Clay Carpenter Diary, 4 April 1872; State Leader, 4, 5 April 1872.

30. Iowa State Register, 5 April 1872; State Leader, 5, 6 April 1872. 
punishment, not revenge, and that juries would not convict if hanging might be the outcome. ${ }^{31}$

Many newspapers across the state joined the Register's campaign. Like the Register, they emphasized the barbarism of the gallows and the disgrace to Iowa of hanging Stanley after twelve years without an execution. ${ }^{32}$ Many other newspapers said nothing, while a few urged retention of the death penalty, citing the need for deterrence and for consultation with the people. ${ }^{33}$ The Dubuque Herald campaigned for retention with special vigor, declaring that if legal hanging were abolished "mobs will frequently step in and do it." It emphasized the probability of murderers sentenced to prison being pardoned and then repeating their crimes. ${ }^{34}$

The retentionist press may have influenced some legislators, but in Des Moines the Register and the Leader held sway. Both newspapers mounted major abolition campaigns, continually printing anti-death penalty items during the days following Bovee's speech. They reprinted powerful editorials from the Davenport Democrat and the Iowa City Press and published lists and comments of reform newspapers. Readers learned of the opposition of Bishop Lee of the Protestant Episcopal Church to the death penalty. An editorial reprinted from the St. Louis Dis-

31. Iowa City Press, 8 April 1872; Iowa State Register, 5 April 1872; Iowa State Weekly Register, 10 April 1872; State Leader, 5 April 1872.

32. Muscatine Weekly Journal, 12 April 1872; Louisa County Safeguard, 18 April 1872; Nashua Post, 12 April 1872; Davenport Democrat, 4, 6, 9, 10, 12, 13 April 1872; Dubuque Times, 6, 10 April 1872; Warren County Leader, 11, 18 April 1872; Council Bluffs Nonpareil, 5 April 1872; Marshall County Times, 11 April 1872; Adair County Reporter, 12 April 1872; Prairie City Index, 5, 19 April 1872; Cedar Rapids Times, 18 April 1872; Maquoketa Excelsior, 11 April 1872; Keokuk Gate City, 10 April 1872; Iowa City Press, 8 April 1872; State Leader, 4 April 1872; Cedar County Post, 17 April 1872; Dexter Herald, Warren County Journal, noted in Davenport Democrat, 10 April 1872; Hamilton Freeman, Wyoming Journal, Henry County Press, noted in Iowa State Register, 13 April 1872.

33. Lyons Mirror, 13 April 1872; Eldora Ledger, reprinted in Warren County Leader, 18 April 1872; Oskaloosa Herald, 11 April 1872; Fairfield Ledger, 11 April 1872; Cedar Falls Gazette, 19 April 1872; Clinton Age, 12 April 1872; Ottumwa Democrat, 11 April 1872; Waterloo Reporter, reprinted in Dubuque Weekly Herald, 17 April 1872; Waterloo Courier, reprinted in Dubuque Herald, 12 April 1872. The Clinton Age, 12 April 1872, supported capital punishment but wanted Stanley pardoned.

34. Dubuque Herald, 10, 13, 17, 20 April 1872. 
patch and a letter from Ohio showed that other states were looking to Iowa to lead on the issue. A lengthy and dignified interview with George Stanley printed in the Register was reprinted throughout the state a few days before his execution was due. The Leader published Bovee's long list of innocent people who had been executed. Doubtless Bovee also inspired the printed claim that Holland had recently abolished the death penalty and that England had ended public hanging. Notices of another public lecture by Bovee appeared with antigallows quotations by Benjamin Franklin and reformer Theodore Parker. Bovee was busy in the lobbies as well as in the press. The Dubuque Times Des Moines correspondent reported that Bovee's lobbying efforts were "seconding the efforts of the Register, ably and efficiently. The near execution of Stanley, at Nevada has been found a good lobby argument." 35

Four days before Stanley's execution was due, the legislature reacted. The powerful Republican John A. Kasson introduced a resolution into the House asking the governor to delay the hanging until the General Assembly had acted on a bill to abolish the death penalty. The House passed the resolution unanimously, and the next day the Senate concurred with only one dissenting voice. The governor immediately postponed Stanley's execution for a month. The same day, Kasson's bill, drafted by Bovee, passed the House with the remarkable majority of 68 to $22 .{ }^{36}$

The following day, the Senate took up the matter of capital punishment. By 32 votes to 14 it adopted a resolution for the Judiciary Committee to report a Senate bill abolishing the death penalty. The reformers expected an easy victory in the Senate's consideration of the House bill, but events proved otherwise. Dubuque Senator Benjamin B. Richards attacked abolitionism as "sickly weakly sentimentalism." Senator John E. Burke of Bremer County cited "all that could be found in history" as evidence that "the gallows was one of society's strong props." The stern Senator Moses A. McCoid, a Methodist, quoted Old Tes-

35. Iowa State Register, 7, 9, 10, 11, 13, 14 April 1872; State Leader, 8, 10, 12 April 1872; Dubuque Times, 13 April 1872.

36. 1872 Iowa House Journal 619-20, 652-53; Iowa City Press, 10 April 1872; 1872 Iowa Senate Journal 517; Muscatine Journal, 10 April 1872. 
tament scriptures. Senator William Larrabee of Fayette County said he "did not wish the Senators to be influenced by the case of the poor culprit brought up here, nor by the teaching of the itinerant preacher (Mr. Bovee), who had been entertaining them with lectures for the few evenings past, but to act cooly and let the law take its course in this case (Stanley's) unfortunate as it was." On the reform side, Quaker Senator John C. Chambers suggested that the prospect of hanging made juries reluctant to convict. Furthermore, "the death penalty did not prevent mob law, as facts showed it, even in this State." Senator Vale's Quaker upbringing was evident in the New Testament quotations he used to answer Senator McCoid. Despite the abolitionists' arguments, the retentionists won the day. Senator Larrabee proposed an amendment to give the jury the option of death or life imprisonment. After the amended bill passed by a vote of 25 to 20, the Muscatine Journal pithily commented, "The action of the Senate on the bill hangs Stanley but modifies the law." 37

The next day, April 11, the abolitionists introduced a motion to reconsider the vote. In opposition, Presbyterian Senator Samuel McNutt argued against hasty change, maintaining that the death penalty was an essential deterrent. Presbyterian Senator John McKean declared that public opinion opposed abolition, and insisted it would lead to lynch law. He claimed that Michigan since abolition had a far greater murder and general crime rate than Iowa. Abolitionist Senator John Shane responded that the population profiles of Michigan and Iowa differed. Moreover, the increase in convictions in Michigan showed that juries would convict more often without capital punishment. Nonetheless, the retentionists won this test vote, 25 to $23 .{ }^{38}$

The two houses were deadlocked. Bovee plunged straight back into the fray, giving another successful public lecture that evening. For the next nine days he worked to change the Senate vote, and two groups of Quakers petitioned the Senate. On

37. 1872 Iowa Senate Journal 531-32, 533-34, 536-38; Muscatine Journal, 11 April 1872 Iowa State Weekly Register, 17 April 1872; Dubuque Times, 16 April 1872.

38. 1872 Iowa Senate Journal 545-48; Iowa State Register, 12 April 1872. 
April 19, Bovee's abolition bill was reintroduced in the House and passed, 54 to 21 . The next day the Senate reversed itself and passed the bill by the remarkable majority of 31 to $14 .{ }^{39}$

A national voice from the days of the old New York Committee for the Abolition of Capital Punishment hailed the breakthrough in Iowa. Horace Greeley, by then a presidential candidate, saluted Iowa in a lengthy editorial in his New York Tribune. "Now that so good an example has been set," he wrote, "it is probable that other States will follow it." 40 Greeley was too optimistic. During the rest of the nineteenth century, only Maine in 1876 and Colorado in 1897 emulated Iowa's example.

Iowa's victory belonged to Bovee. The Register summarized his campaign. "Beginning, he was told there was no hope; that made no difference. Succeeding in half-way manner, he refused to accept the situation. His refusal . . . led on to full success, thanks, largely to his adhesion to the magic of undiscouraged effort." The Register praised Bovee's skills as a speaker, worker, and manager. The Leader echoed the Register's tribute. "With unfaltering faith and unabated zeal he 'fought the good fight' which has wiped out the foul stain from the fair page of our statute book." The Keokuk Constitution went to the heart of the matter. "The pressure was too heavy upon some of those who had been voting nay heretofore, and they 'slopped over'. Mr. Bovee, who has been lecturing and working in season and out of season for this result, was astonished as much as any one at his complete success. He had no full conception of the facility with which an Iowa legislator can change his vote on an important measure." 41

The change in votes on abolition between the 1870 and 1872 legislatures was dramatic. In the House, the reformers increased their share of the vote from 45 percent in 1870 to 72 percent in 1872; in the Senate, they went from 39 percent to 69

39. Iowa State Register, 12 April 1872; 1872 Iowa Senate Journal 576, 595, 68586; 1872 Iowa House Journal 827-28; "An Act in Relation to Capital Punishment, and Regulating Pardons," chap. 242, Laws of Iowa, 1872, pp. 139-40. Stanley was imprisoned in Fort Madison until he was pardoned in 1902. Iowa State Register, 21 April 1872; Payne, History of Story County, 1:331. 40. New York Tribune, 27 April 1872.

41. Iowa State Register, 21 April 1872; eulogy reprinted in New York Tribune, 27 April 1872; State Leader, 22 April 1872; Keokuk Constitution, 23 April 1872. 
percent. All five senators who voted to abolish in 1870 and voted again in 1872 remained abolitionist. But four of the eleven senators who voted to retain in 1870 and voted again in 1872 switched sides in 1872 and voted to abolish. ${ }^{42}$ Building on solid reform minorities of 35 to 45 percent in the years 1856 to 1870 , Bovee achieved more than a two-thirds majority for abolition in both houses in 1872 (see fig. 1). The especially dramatic shift in votes during the course of the 1872 legislative session itself underscores Bovee's extraordinary influence, for eight of the twenty-five senators who voted to retain capital punishment on April 11 changed sides just nine days later.

The 1872 Iowa legislature was not particularly reformminded. It did pass a minor temperance bill, and in its adjourned session in 1873 it took the more significant step of reducing legal disabilities of married women. But the Senate blocked the vital resolution to put a constitutional amendment on woman suffrage to the voters. By contrast, the 1870 legislature had been more reformist. It, too, had passed a minor temperance law, and it had approved the woman suffrage resolution (Iowa's constitution provided that such a resolution had to be approved by two successive legislatures). Furthermore, the 1870 legislature had voted to admit blacks and women to the bar, and had ratified the Fifteenth Amendment to the United States Constitution prohibiting abridgment of the right to vote on racial grounds. Yet it was the reform-minded 1870 legislature that retained the death penalty, while the less reformist 1872 legislature voted overwhelmingly to abolish it. ${ }^{43}$

The abolition of the death penalty by Iowa in 1872 was sui generis. No other state had abolished capital punishment since 1853. No national or Iowa state organization to banish capital

42. The four senators who changed to abolition between 1870 and 1872 were Senators Campbell, Havens, Hurley, and Ireland. The eight who changed to abolition during the 1872 session were Senators Boomer, Campbell, Dague, Fitch, Howland, Hurley, Willett, and Wonn. Senators Campbell, Havens, and Wonn would vote to restore the death penalty in subsequent sessions.

43. Dan Elbert Clark, "History of Liquor Legislation in Iowa, 1861-1878," Iowa Journal of History and Politics 6 (1908), 351-57; Louise R. Noun, Strong Minded Women (Ames, 1969), 125-35, 217-22; Des Moines Bulletin Legislative Supplement, nos. 28, 29, 3, 5 March 1870; J. Van der Zee, "Amendments to the Constitution of the United States Proposed in the State Legislature of Iowa, 1846-1909," Iowa Journal of History and Politics 7 (1909), 382-89. 
punishment had existed since the decline of the societies in the $1850 \mathrm{~s}$. And there is no evidence that the Iowa electorate's views on capital punishment were made known to legislators in 1872 or played any part whatever in the abolition of the death penalty. ${ }^{44} \mathrm{~A}$ unique combination of a legislature confronted by the awesome decision of whether Stanley should live or die, an abolitionist governor, an antigallows press campaign spearheaded by the Des Moines newspapers, the petitions of Quakers, the pleas of Stanley's Catholic priests, and, above all, Bovee's remarkable crusade achieved the abolition of the death penalty in Iowa.

It would last for only six years.

THE GENERAL ASSEMBLY sat in adjourned session in 1873 to revise the Code of Iowa. When the Senate considered the penalty for murder, Senator McCoid introduced an amendment to restore capital punishment, declaring that abolition had opened the floodgates of crime. Senator Larrabee concurred that murders were increasing. In an oblique compliment to Bovee, he said, "Members were besieged by a strong lobby last winter which ... no doubt had its influence on the course they pursued." 45 The restoration amendment was defeated, 24 to 13. Yet without Bovee's "strong lobby," those who favored capital punishment had increased their share of the vote from 31 percent to 35 percent, and three senators who had voted for abolition in 1872 now changed sides. Senator McCoid, a former district attorney, entered a formal protest in the Senate Journal based on the familiar Old Testament arguments. ${ }^{46}$ The trend towards restoration continued in 1874 when the new House voted to instruct the Judiciary Committee to report a bill to reinstate the death penalty. The resolution's defeat, 46 to 41 , was a "narrow escape" for the antigallows forces, even though there is no evidence of strong popular opposition to the abolition of the

44. See, for example, Fort Madison Plain Dealer, 2 May 1872; Waterloo Reporter, quoted in Dubuque Weekly Herald, 17 April 1872.

45. Iowa State Register, 11 February 1873.

46. 1873 Iowa Senate Journal 204, 213; Code of Iowa, 1873, §§ 3848-49, p. 600. Senators Havens, Leavitt, and Wonn changed to restoration. Senator Maxwell changed from retention to abolition. Havens and Wonn had been among those who had changed sides to abolish the death penalty in 1872 . 
death penalty in the 1873 elections or by way of petitions to the 1874 session of the legislature. ${ }^{47}$

After a dramatic lynching in Des Moines in December 1874 , however, opinion swung decisively in favor of restoration. In June a murdered body had been found outside a brothel in Des Moines. Newspapers vividly reported the three-weeklong trial of bartender Charles Howard. A member of the bench described the evidence as "a contest between desperadoes on one side and prostitutes and pimps on the other." ${ }^{\prime 4}$ The trial caused tremendous excitement, not least because there had been six murders in Des Moines in the previous four years. Several were unsolved, and Howard was the first person charged to be tried. While the jury deliberated for four days, the Leader, in a thinly veiled article, advocated lynching, and the juror who held out for acquittal received a death threat. ${ }^{49}$

Leaders of the Des Moines bar advised the presiding judge, Hugh Maxwell, to dismiss the jury. Instead he ordered them to reach a verdict. The jury convicted Howard of murder in the second degree. In a thronged courtroom Judge Maxwell sentenced Howard. Calling Howard "a fiend" and lynch mobs "our best citizens," he declared that Howard was "guilty of murder in the first degree, and ought to be punished accordingly." After proclaiming "most firmly that capital punishment ought to be sustained," Judge Maxwell sentenced Howard to life imprisonment. That night a hundred masked men stormed the Des Moines jail and hanged Howard from a lamppost in the courthouse yard. ${ }^{50}$

The press raised an outcry. Newspapers across the state overwhelmingly blamed the lynching on abolition, reasoning that Howard should have been legally hanged. According to the Keokuk Constitution, the lynching was "the natural result of

47. Muscatine Journal, 23 February 1874; 1874 Iowa House Journal 277-78. The five representatives in 1874 who had voted to abolish in 1872 all did so again in 1874 .

48. Iowa State Register, 18 December 1874.

49. History of Polk County, Iowa (Des Moines, 1880), 525-26; State Leader, 11 December 1874.

50. Report of the First Annual Meeting of the Iowa State Bar Association Held at Des Moines, Iowa, June 27 and 28, 1895, 58-59; Iowa State Register, 15 December 1874 . 
the abolishment of hanging by law by the damphool radicals. ${ }^{\prime 51}$ There were numerous calls for restoration. ${ }^{52}$ The Warren Record commented, "it is hard to find a man or woman in [Des Moines] that would not vote for capital punishment." ${ }^{23}$ A few newspapers continued to support abolition. The Dubuque Times, recalling that there was just as much lynching when capital punishment was the law, placed much of the blame for the lynching on Judge Maxwell's speech. ${ }^{54}$

Howard's lynching crystallized Iowa opinion in favor of restoration. There was a terrible irony in this. As the antigallows Davenport Gazette pointed out, Howard had been convicted of second degree murder and so would not have hanged under the old law anyway. Furthermore, the Gazette asserted, many people thought Howard innocent. ${ }^{55}$ Beyond question, there was a reasonable doubt as to Howard's guilt. Even the prosecutor later said, "I did not believe then, and do not believe now, that [Howard] was guilty." 56

A few days after Howard's death, the newspapers carried an incorrect report of another lynching, and rumors of a wave of lynchings sank into public consciousness. ${ }^{57}$ After a second bona fide lynching in June 1875, the local press called for resto-

51. Keokuk Constitution, quoted in Iowa State Register, 17 December 1874.

52. Boone County Democrat, 23 December 1874; Oskaloosa Herald, quoted in Iowa State Register, 19 December 1874; Winterset Madisonian, 27 December 1874; Knoxville Journal, 17 December 1874; Washington County Press, 23 December 1874; Council Bluffs Nonpareil, quoted in Iowa State Register, 17 December 1874; Ottumwa Democrat, quoted in State Leader, 18 December 1874; Lansing Mirror, 18 December 1874; Delhi Monitor, 24 December 1874; Indianola Herald, quoted in Iowa State Register, 19 December 1874; Waverly Republican, 24 December 1874; Fayette County Union, 23 December 1874; Iowa State Leader, 15, 16 December 1874; Dubuque Herald, 17, 18 December 1874; Belle Plaine Union, 24 December 1874.

53. Warren Record, 24 December 1874.

54. Dubuque Times, 18, 19 December 1874. See also Boone Standard, 26 December 1874. Some newspapers blamed Judge Maxwell for the lynching without commenting on the death penalty. See, for example, Keokuk Gate City, 18 December 1874, citing Des Moines Journal.

55. Davenport Gazette, 20 December 1874.

56. Report, Iowa State Bar Association, 59.

57. State Leader, 19 December 1874, 1 March 1875; Iowa State Register, 17, 20

December 1874, 11 May 1875. 
TABLE 1

CRIMINAL CONVICTIONS IN IOWA, 1868-1877

\begin{tabular}{|c|c|c|c|c|c|c|}
\hline & \multicolumn{3}{|c|}{ Murder } & \multirow[b]{2}{*}{$\begin{array}{c}\text { Total } \\
\text { Murders }\end{array}$} & \multirow[b]{2}{*}{ Rape } & \multirow[b]{2}{*}{$\begin{array}{c}\text { Total } \\
\text { Convictions }\end{array}$} \\
\hline & $\begin{array}{c}\text { First } \\
\text { Degree }\end{array}$ & $\begin{array}{l}\text { Second } \\
\text { Degree }\end{array}$ & Unclassified* & & & \\
\hline 1868 & 1 & 2 & 0 & 3 & 2 & 421 \\
\hline 1869 & 0 & 3 & 0 & 3 & 2 & 439 \\
\hline 1870 & 3 & 1 & 0 & 4 & 0 & 537 \\
\hline 1871 & 0 & 3 & $1^{*}$ & 4 & 1 & 739 \\
\hline 1872 & 0 & 1 & 2 & 3 & 1 & 616 \\
\hline 1873 & 0 & 0 & 7 & 7 & 0 & 896 \\
\hline 1874 & 0 & 1 & $1^{*}$ & 2 & 3 & 1,330 \\
\hline 1875 & 1 & 10 & 4 & 15 & 8 & 1,317 \\
\hline 1876 & 1 & 5 & 5 & 11 & 6 & 1,568 \\
\hline 1877 & 3 & 11 & 0 & 14 & 2 & 1,672 \\
\hline
\end{tabular}

SOURCE: Report of the Secretary of State in Relation to the Criminal Returns of the State of Iowa for the Years 1876 and 1877, 157-58.

NOTE: Some counties reported murder convictions without classifying them. For example, the one unclassified murder in 1871 was the conviction of George Stanley, a murder in the first degree; the one unclassified murder in 1874 was the conviction of Charles Howard, a murder in the second degree.

ration of capital punishment, emphasizing "the frequent recurrence of murders." ${ }^{\prime 5} 8$

The failure of financier Jay Cooke in September 1873 triggered a national depression and a real crime wave. ${ }^{59}$ Annual statistics of criminal convictions in Iowa submitted to the 1872 legislature had shown three second degree murders and one unclassified murder for the year ending October 1871. By October 1875 these figures had leapt to ten second degree murders, four unclassified murders, and one first degree murder. There were nine assaults with intent to commit murder in 1871, and sixteen in 1875 . There was one rape conviction in 1871 , and a staggering eight convictions in 1875 . Total convictions nearly doubled from 739 in 1871 to 1,317 in 1875 (see table 1). The climate for restoration was favorable.

In early 1876 bills to restore capital punishment were introduced in both houses. The Register reported, "The sentiment of the press is strongly and overwhelmingly in favor of the restoration of the old law. We only know some dozen

58. Ottumwa Democrat, 8 July 1875; Ottumwa Courier, 30 June 1875.

59. Eric F. Goldman, Rendezvous with Destiny (New York, 1953), 29-31. 
papers which oppose it, and undoubtedly public sentiment is largely in favor of it." Even the Dubuque Times and Davenport Gazette had moved into the gallows lobby since the Howard lynching. The Times did so because "more murders have been committed in Iowa since the repeal of the death penalty than had occurred in a dozen years theretofore." The Gazette said that Iowans had never wanted abolition. "Then came a series of murders, and of lynch-law executions such as had never before disgraced the State, and the existing demand followed." The Register remained on the abolitionists' side, however, because "the law is right" and "should at least be given a fair chance to demonstrate its wisdom or its weakness." ${ }^{60}$

Petitions on both sides flooded into the legislature. The main Quaker petition caused Presbyterian minister Rev. William J. Gill to thunder from his Des Moines pulpit to a congregation containing many legislators. Quaker Senator Elias Jessup promptly responded in the press, which was crammed with death penalty news and letters. ${ }^{61}$ Lurid crimes continued. Three murders by teenaged boys were reported in ten days. The attempted rape of a little girl in Dubuque led to speculation of lynching. ${ }^{62}$

In the House the antigallows legislators argued familiar propositions: the reluctance of juries to convict when the penalty was death; life imprisonment as sufficient deterrent; the risk of executing the innocent; and the teachings of Jesus Christ. They wanted abolition to be given a fair trial: if the public had the same responsibility as the General Assembly, "they who favor the reenactment of the death penalty would pause and reflect." They pointed to the example of Maine, which had just abolished capital punishment. They also noted that crime had decreased after the reform in states that had abolished capital punishment. Moreover, murder had increased in hanging states just as much as in Iowa. On the restorationist

60. Iowa State Register, 29 January 1876; Dubuque Times, 21 January 1876; Davenport Gazette, 24 January 1876.

61. 1876 Iowa Senate Journal 534-35; 1876 Iowa House Journal 658; Iowa State Register, 1 February 1876. See also ibid., 9, 19, 25, 26, 28, 30 January, 5, 6, 8, 11, 15, 19 February 1876.

62. Iowa State Register, 30 January, 9, 22 February 1876. 
side, speaker after speaker referred to the increase in crime in Iowa since abolition. They urged that the state's abdication of its responsibilities led to lynching, citing in particular Howard's case. They reiterated the arguments based on Old Testament scriptures. Finally, they insisted that the people had never asked for abolition, and now the people demanded restoration. After a three-day debate, the restoration bill passed the House, 55 to $42 .{ }^{63}$

The Senate produced the drama. Dubuque Senator Dennis N. Cooley introduced the restoration bill, arguing that "there was a vast increase of crime ... that the present law was never the real sentiment of the people." Moreover, "abolishment has had the effect to increase mob law." Quaker Senator Jessup dominated the antigallows side of the debate. Calling the bill "a step backwards towards barbarism," he used statistics to show that, allowing for population change, convictions in Iowa for first degree murder had actually decreased in the four years since abolition compared with the four prior years. On the third reading of the bill, the restorers won the vote, 25 to 20 . They claimed that the bill therefore passed because they had obtained a majority of the forty-nine sitting senators (one member having just resigned). However, the president of the Senate ruled that the Constitution required 26 votes for passage-a majority of those elected. Thus, the restoration bill failed. ${ }^{64}$

But the crime wave and lynching had transformed opinion since 1872. In the House the pro-hanging share of the vote had risen from 28 percent to 57 percent; in the Senate from 31 percent to 56 percent. There was a particularly dramatic shift among the six senators who had voted to abolish in 1872 and who voted again in 1876, as four of the six changed sides and supported restoration of the death penalty. ${ }^{65} \mathrm{Had}$ those four not reversed their vote, restoration would have been defeated,

63. 1876 Iowa House Journal 463-64; Iowa State Register 26, 27 February, 1 March 1876; Dubuque Times, 26, 29 February, 4 March 1876.

64. 1876 Iowa Senate Journal 313; Iowa State Register, 26, 27 February 1876; Dubuque Times, 25 February 1876; Muscatine Journal, 28 February 1876.

65. The senators who changed from abolition in 1872 to restoration in 1876 were Senators Campbell, Dashiell, Wonn, and Young. Campbell and Wonn had been among those who had changed sides to abolish the death penalty in 1872 . 
24 to 21 . With the shift, however, the antigallows share of the vote reverted to the level typical during the twelve years before abolition (see fig. 1).

The crime wave continued. In October 1877 the Dubuque Times reported that in Grundy Center alone there were five men awaiting trial on murder charges. A crowd was threatening to lynch the most recent, a man accused of murdering a young girl. The editorial regretted the legislature's failure to restore the death penalty, and hoped "the next General Assembly will heed the large and growing discontent over the abrogation of the death penalty." The following month the third lynching since abolition took place. An attempted robbery in Warren County resulted in the shooting of a young woman. Near death, she identified a man named Reuben Proctor as one of her assailants. After Proctor was arrested, forty armed men overpowered his guards and hanged him from a scale beam. ${ }^{66}$

A chorus of newspapers called for restoration. The Webster County Gazette said, "Let our next Legislature consider this matter in the light of experience, and the rapid increase of crime in our State, and restore the death penalty." The Tipton Advertiser added, "The coming Legislature of Iowa will disappoint expectations if it does not vote to restore to the statute books the proper penalty for murder."67

The change in opinion since abolition was vividly demonstrated by the Iowa State Register. The Register, edited since 1870 by James S. "Ret" Clarkson, who had made it into the state's dominant newspaper, had played a large part in abolition and had continuously resisted restoration. But an editorial in November 1877 announced, "It is plain that there is a rising tide in this State in favor of the restoration of the death penalty, and also in favor of making rape equally with murder a capital crime." The writer reported that capital punishment had recently been an election issue in several districts where pro-

66. Dubuque Times, 3 October 1877; Cedar Rapids Republican, 3 October 1877; Iowa State Register, 16 November 1877.

67. Webster County Gazette, 30 November 1877; Tipton Advertiser, 22 November 1877. Other newspapers to come out for restoration included the Vinton Eagle, 21 November 1877, and the Mills County Republican, reprinted in Iowa State Register, 1 December 1877. 
death penalty candidates had been elected. The newspaper that had campaigned against "the barbarism of the gallows" in 1872 and had never doubted Stanley's guilt now concluded, "As to the murderer, if he is guilty, and absolutely known to be, we would say kill him, and the sooner the better." The Register editorial was a landmark on the road to restoration. ${ }^{68}$

The trend of criminal convictions in Iowa explains the increased demand for the death penalty for murder and rape (see table 1). No convictions for first degree murder were reported in the year ending October 1871, although there was one unclassified murder conviction (Stanley's); in 1877 there were three first degree murders. Second degree murders increased from three in 1871 to eleven in 1877. Rape convictions had risen from one in 1871 to eight in 1875 , six in 1876 , and two in 1877. Assaults with intent to commit rape went from four in 1871 to twenty in 1876 and thirteen in 1877 . Total convictions more than doubled, from 739 in 1871 to 1,677 in 1877 .

In 1878 voters on both sides of the issue again presented petitions to the legislature. Three restoration bills were introduced in the House. One of them sought the death penalty for rape, but that clause failed to pass the Judiciary Committee. ${ }^{69}$ While the legislature was in session, press reports reflected the continuing crime wave and lynching atmosphere. A rape and murder in Council Bluffs were prominently reported, as was a rape in Ottumwa. There was speculation about lynching in both cases. ${ }^{70}$

The Senate debated a bill to restore the death penalty for first degree murder but postpone execution for a year. The debate attracted large crowds to Des Moines, and capital punishment was discussed all over the city. Representatives and spectators filled the gallery as fifteen senators spoke over a three-day period. The Burlington Hawkeye afterwards com-

68. Iowa State Register, 20 November 1877.

69. 1878 Iowa House Journal 684, 83, 180; 1878 Iowa Senate Journal 558; Iowa State Register, 20 January 1878.

70. Iowa State Register, 27 January, 21, 22, 23, 28 February 1878; Iowa State Weekly Register, 22 February 1878. 
mented, "The debate will go down in the history of the state as a notable one."71

Senator McCoid once again argued from principle. The exceptional heinousness of murder, he insisted, called for the death penalty. Society owed protection to its members, and nothing to convicted murderers. After appeal, a murderer's case "is one of unquestioned conclusive guilt. ... It is the high duty of government ... to administer punishment equal to the crime." He concluded that the death penalty "is founded upon the plainly expressed will of God." Inveterate retentionist Senator Larrabee and others emphasized the great increase in crime and lynching since abolition. A family tragedy had caused Senator James M. Shelley to cast aside his Quaker upbringing. "He had ... lost a married niece, the mother of two lovely children, and the little ones themselves were killed with her, and the murderer had never been adequately punished." On the reformers' side, Senator William A. Foster, an outstanding defense lawyer, emphasized the execution of innocent people and argued that juries would not convict with the death penalty. Reenactment would be a retrograde step "when this State has always been in the van of civilization." Senator John S. Woolson said the death penalty violated the constitutional provision forbidding cruel and unusual punishment. Senator Joshua Miller supported abolition "from a personal knowledge, having been a shooter himself and tried for the offense." Senator John Rumple, a free thinker, asked, "Did not Christ abrogate the death penalty in his Sermon on the Mount?" But the author of the bill, Senator Samuel D. Nichols of Guthrie County, clinched the argument by declaring that "the people of the state demand that something should be done, because crime is on the increase." Heeding that demand, the Senate passed the restoration bill on its third reading, 28 to $19,{ }^{72}$

The House considered a separate restoration bill which gave the jury the option of deciding on hanging or life imprisonment. In a half-day debate, Representative Edward Taylor

71. Iowa State Register, 28 February 1878; Atlantic Telegraph, 6 March 1878; Burlington Hawkeye, 5 March 1878.

72. Iowa State Register, 28 February, 1, 2 March 1878; State Leader, 27, 28 February, 1 March 1878; 1878 Iowa Senate Journal 219-20. 
argued that mob law did not result from abolition. Twenty years earlier there had been so many lynchings that Governor Grimes had to issue a special proclamation. Hard times, not abolition, was the cause of the current crime wave. Further, in the category of crime relevant to the death penalty, there were six first degree murder convictions in Iowa in the six years before abolition, and five in the six years since. Taylor was supported by Representative Henry Rickel, who mourned, "There is something melancholy in the fact that ministers of our Christian churches are placing their printed sermons on our desks, in which a clamorous appeal is made for blood!" Three restorers spoke briefly. They emphasized the Old Testament arguments, the deterrent effect of the death penalty, and the increase in crime. Representative Moses Bloom referred graphically to incidents of rape and murder, urging legislators to "let all the wicked and depraved men in the State know that there is a law ... that will require their own lives as a penalty for the commission of murder."73

The vote in the House on the third reading was an overwhelming 61 to 32 to restore capital punishment. ${ }^{74}$ This bill reached the Senate on the final day of the session. The Senate passed the House bill, 30 to $16 .^{75}$ After six years, the viewpoint of Senators McCoid and Larrabee had triumphed. Iowa became the first American state and the first jurisdiction in the Englishspeaking world to restore the death penalty. ${ }^{76}$

Nothing highlights the change of attitudes since 1872 more than the Register's reaction to the news. In 1872 that newspaper had greeted abolition joyfully, proclaiming, "The Register's arm and ax were early raised for the chopping down of the Gibbet in Iowa, and our work has been a labor of love. ... [We are] confident we have been in the Right, and that Time will so approve it." The day after the Senate passed the

73. Iowa State Register, 9 March 1878; State Leader, 9 March 1878; Muscatine Weekly Journal, 27 March 1878.

74. 1878 Iowa House Journal 353. An abolitionist House sifting committee tried to block the bill from going to the Senate. It was overcome in a series of votes of similar proportions. Ibid., 596-99, 602, 604-5.

75. 1878 Iowa Senate Journal 506; "An Act to Restore Capital Punishment," Laws of Iowa, 1878, pp. 150-51.

76. Bowers, Legal Homicide, 9, 146. 
restoration bill the Register praised the jury option clause in the bill. "Now when a man commits murder in Iowa the jury trying him can hang him if he deserves it, or send him to the penitentiary for life, as they choose. This optional verdict is a good ground on which to rest this controversy. ... Under this law the veriest villain can get his just deserts." ${ }^{\prime 77}$

There was always a rigid block of legislators in favor of the death penalty. They had only failed to restore it in 1876 because they had not achieved a technical constitutional majority in the Senate. In 1878 their numbers were augmented by legislators influenced by the electorate, the continuing wave of murder and rape, and the atmosphere of lynching. In the House, the restorers had increased their share of the vote from 28 percent in 1872 to 66 percent in 1878 . In the Senate, their vote had risen from 31 percent in 1872 to 65 percent in 1878 ; between 1876 and 1878 alone their share had increased from 56 percent to 65 percent. The nine senators who had voted to abolish in 1876 and voted again in 1878 confirmed the trend. Two of these changed sides in 1878 and supported restoration..$^{78}$ In all the votes on capital punishment between 1851 and 1876, the lowest proportion of the vote the antigallows forces had ever achieved was 35 percent in 1856 . By 1878 the wheel had turned full circle, and their strength was back at its lowest point, with votes of 34 and 35 percent (see fig. 1).

In 1878 only two senators remained from those who had voted to abolish the death penalty in 1872. Senator Horatio A. Wonn initially supported hanging in 1872, but under Bovee's spell he joined the reform landslide. He recanted in 1873 and voted to restore the death penalty in 1876 and 1878 . Senator John L. McCormack, in contrast, opposed the death penalty throughout the entire period. These two senators precisely represent the fortunes of the antigallows vote in the Iowa legislature in the 1870 s.

Lynchings, murders, and public opinion were mainly responsible for bringing capital punishment back to Iowa. The lynching of Howard gave maximum publicity to the belief that if the state would not hang murderers, mobs would. Proctor's

77. Iowa State Register, 21 April 1872, 27 March 1878.

78. The two were Senators Teale and Wright. 
lynching in late $1877 \mathrm{kept}$ mob "justice" in the forefront of legislators' minds. Also, murder increased dramatically during the six years without the gallows. Legislators chose to attribute this increase to the abolition of capital punishment. By 1878 these factors had turned the press overwhelmingly in favor of the hangman, and in both 1876 and 1878 citizens petitioned the legislature for restoration. Moreover, in 1877 voters actually elected some legislators committed to bringing back the death penalty. The cumulative result in 1878 was the massive reversal of the 1872 vote and the restoration of capital punishment.

MANY STATES later imitated Iowa by abolishing capital punishment and restoring it not long afterwards. Maine abolished the death penalty in 1876 and restored it in 1883-and then reabolished it in 1887. Between 1897 and 1920, Colorado, Washington, Oregon, Tennessee, Arizona, and Missouri all abolished and restored capital punishment within a few years. The reasons for the restorations, where they are known, were not unlike those in Iowa-specific murders, fear of a crime wave, or lynchings. In the next wave of reform, Delaware abolished the death penalty in 1958, only to restore it in 1961. In 1965 Iowa reversed itself, reabolishing capital punishment. ${ }^{79}$

The history of the death penalty during Iowa's first forty years shows the power a single dedicated voice can have. One sermon by the Reverend Silas Hazzard in 1851 prevented the abolition of capital punishment. Then Marvin Bovee's crusade in 1872 secured its abolition.

The different nature of the decisions to abolish and to restore the death penalty is of special interest. Responding to reports of an increase of murder and lynching, the 1878 legislature theorized that capital punishment would be a deterrent and restored it. The 1872 legislature, on the other hand, had to consider more than a theoretical argument: it had to decide

79. Bedau, The Death Penalty in America, 22-24; Edward Schriver, "Reluctant Hangman: The State of Maine and Capital Punishment 1820-1887," New England Quarterly 63 (1990), 271-87. Tennessee retained the death penalty for rape in 1915. Bedau, The Death Penalty in America, 24. 
whether George Stanley should hang. As a leading member of the House wrote four days before the scheduled execution, "This brings home to every legislator the responsibility of saying whether a fellow being shall be killed by the State." ${ }^{80}$ Faced with the actual decision of whether a man should live or die, the legislature voted overwhelmingly that he should live.

80. John Irish, quoted in the Iowa City Press, 8 April 1872. 
Copyright of Annals of Iowa is the property of State of Iowa, by \& through the State Historical Society of Iowa and its content may not be copied or emailed to multiple sites or posted to a listserv without the copyright holder's express written permission. However, users may print, download, or email articles for individual use. 